\title{
The Khanty Mother of God and the Finnish woman with deep blue eyes
}

La mère de Dieu khantye et la Finnoise aux yeux bleus

Handi Jumalaema ja tema süvameresilmadega soome õde: „Märgitud“ (1980) ja "Jumalaema verisel lumel" (2002)

Elle-Mari Talivee

\section{(2) OpenEdition}

1 Journals

Electronic version

URL: https://journals.openedition.org/efo/3298

DOI: $10.4000 /$ efo.3298

ISSN: 2275-1947

Publisher

INALCO

Printed version

Date of publication: 1 January 2014

ISBN: 978-2-343-05394-3

ISSN: 0071-2051

\section{Electronic reference}

Elle-Mari Talivee, "The Khanty Mother of God and the Finnish woman with deep blue eyes", Études

finno-ougriennes [Online], 46 | 2014, Online since 09 October 2015, connection on 08 July 2021. URL http://journals.openedition.org/efo/3298 ; DOI: https://doi.org/10.4000/efo.3298

This text was automatically generated on 8 July 2021.

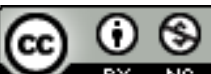

Études finno-ougriennes est mis à disposition selon les termes de la Licence Creative Commons Attribution - Pas d'Utilisation Commerciale 4.0 International. 


\title{
The Khanty Mother of God and the Finnish woman with deep blue eyes
}

\author{
La mère de Dieu khantye et la Finnoise aux yeux bleus \\ Handi Jumalaema ja tema süvameresilmadega soome õde: „Märgitud“ (1980) ja \\ „Jumalaema verisel lumel“ (2002)
}

\section{Elle-Mari Talivee}

1 In the following article, similarities between two novels, one by an Estonian and the other by a Khanty writer, are discussed while comparing possible resemblances based on the Finno-Ugric way of thinking.

\section{Introduction}

2 One of the writers is Eremei Aipin, a well-known Khanty writer (born in 1948 in Varyogan near the Agan River), whose works have been translated into several languages. He has been a member of the Soviet, Russian and regional parliaments. Aipin has also been a dedicated defender of the rights of his nation, and the peoples of the north in his works. ${ }^{1} \mathrm{He}$ is said to have been the first to speak of the northern nations differently: of them not fitting into the world of towns and oil (Toulouze 1999, p. 2004).

3 Arved Viirlaid (born in 1922 in Harjumaa) is an Estonian living in Canada, the most translated of the Estonian exile writers, with an interesting biography. He was mobilized into the Red Army in 1941, refused to serve there and was a "Forest Brother" in World War II. He fought in the Continuation War in Finland in Infantry Regiment 200 (consisting of Estonians) and in 1944 again in Estonia against the Red Army. He managed to go into exile in Sweden, later in England and Canada, and there continued fighting through his poetry and later his prose. He has, throughout his works, described the fate of Estonians in WW II and during the post-war period. ${ }^{2}$ During the Soviet occupation of Estonia, Viirlaid was a strictly forbidden author. 


\section{The two novels}

Both of the novels discussed here are based on real historical events. Aipin's Mother of God in Blood-Red Snows tells about the events of an armed uprising of the Khanty and Nenets people called the Kazym War, which took place in the 1930s. The Khanty resisted with force the taking of their children away from their families against their will and being placed in boarding schools by the Soviet authorities. In addition, they were offended by the authorities showing absolutely no respect for the holy places of their nation. The uprising was followed by severe repression. Aipin had, in the first edition, included a selection of archive documents connected with the uprising, and the author's imagination is mixed with local oral history. The wider meaning of the novel symbolizes the loss of a way of life, the vanishing meaning of this life, and of a small nation gradually and then suddenly losing the right to live in its traditional way - or to live at all. Art Leete has concluded that, in the perspective of the local nations, most of the problems of the Kazym War came from the question of the worldview, or the mentality (Leete 2002, p. 187).

In Estonian literature, the corresponding period would actually be the decades after World War II. As a result of the War of Independence (1918-1920), Estonia was sovereign for twenty years and therefore the Stalinist repression of the thirties, which significantly shattered the nations inside the Soviet Union, did not have an effect on Estonians. Estonia was occupied in 1940 and then the same schemas were exerted here: arrests and death sentences, the deportation of thousands, and the foundation of the kolkhoz system. Religion of any kind was to be rooted out completely. This period and its after-effects were a topic in the Estonian poetry of Hando Runnel and Jaan Kaplinski decades later. There is a difference: Runnel and Kaplinski mostly wrote about these events "between the lines", as it was forbidden to write directly and everything was strictly censored, while Aipin and Viirlaid both had the opportunity to write about this pain openly.

6 In Aipin's novel Mother of God in Blood-Red Snows the Kazym War has already begun. A Khanty woman is heading towards her home village with her four children after meeting a Red Army group. The soldiers have killed her husband and eldest son, as well as their reindeer, except for two which the family had hidden a day before. The protagonist is simply known as the Mother of Children - according to the tradition of her people - and on the way she loses, one by one, almost all her children as an aeroplane of the Red Army attacks them repeatedly. The deaths of her loved ones are so painful that she herself wants to die, and dreams of the World of the Dead. But she suppresses her desire until she can save at least one of her kids, the last and the youngest one, the little boy Savva, and she finally finds the strength to bring him to a Khanty village.

7 Arved Viirlaid's novel Marked is about the Estonian soldiers having fought as volunteers in the Finnish Continuation war. His heroes were in 1941 mobilized to the Red Army and instead of sending to the front taken to Siberia, to labour battalions, as men from the newly occupied territories as Estonia then was could not been trusted. Because of the success of the Germans at last also they were used as soldiers, sent to the front and fought in the Red Army. In the novel some of them change sides and manage to escape to Finland. There they volunteer in the Continuation War to repay in kind for their own sufferings, for the loss of their beloved ones and homeland. Those who after the war 
chose the exile in Finland, were in 1947 extradited to Russia as war criminals, and sent to labour camps in Siberia, as Finland could then not stand up to the demand of the Soviet Union. Most of them perished there and had to be forgotten for years. The novel describes parallel their first journey to Siberia and the months in Finland after the arrest.

\section{Novels as acts of memory}

8 Literature is said to be both an act of memory and a new interpretation, by which every new text is etched into memory space (Lachmann 2008, p. 301). To my mind, a concept from the border of history and literature, "post-memory" (Marianne Hirsch's term), has to be kept in mind here as well. It is distinguished from memory by distance and from history by a deep personal connection, and is therefore a very powerful and very particular form of memory (Caldicott, Fuchs 2003, p. 20).

laid, who was himself first a soldier in the Finnish Continuation War and then fought against the Red Army in Estonia in 1944, escaped to Sweden, therefore he was not sent to Siberia. He heard about those events from other Estonians in exile. The Kazym War, in which resistance still played an important role in identity, could not be discussed openly during the Soviet time, and so was preserved in memory, in silence. ${ }^{3}$

Actually, there are many parallels in these two novels besides the experiences of two little nations that happened to be under the sword, as Mika Waltari has said. In a strange way, there are even cross references to each other's space described in both novels. For example, Viirlaid writes often about the Finno-Ugric kinship, and one of his characters, Armin, manages to escape from a labour camp in Siberia with the help of the Ostyak people (another name for the Khanty). Aipin's White Army officer who stays for a while with the Khanty heads to Finland, a country where freedom already exists.

\section{Other parallels}

11 In both books, the story is largely told from the viewpoint of a woman, a Khanty wife by Aipin, and in Viirlaid's novel a very important position is given to Irja, a young Finnish wife married to the Estonian artist Eigo Arget. They share the pain of losing their families, and also many things very deeply original and maternal.

We learn more about Irja from the background, while the Khanty Mother of Children tells many things from her point of view.

The Mother of Children is middle-aged: this is her second marriage and two of her children are already grown-ups living elsewhere. She is rather short, and probably has bog-green eyes, as her children are depicted as having. She has many skills, has been the head of the family since the death of her father and first husband, and she is very brave; we could say that she does not give up in the world known to her. In the book, she has to fight against the invasion of an alien world.

14 Viirlaid's book actually has several female characters, all of them wives or girlfriends of Finnish-Estonian soldiers, but they seem somehow to blend together in the image of Irja. Irja is young, she comes from a little seaside Finnish town, and she seems to have something essential for living, some type of support that others do not have. Irja is the only one of the Finnish wives of the Estonian soldiers to get her husband back, although 
not until she is in exile in Sweden, as Eigo Arget finally escapes from prison. But she loses her little son and her homeland.

Both novels are journeys from one place to another: the Khanty Mother of Children goes back to her home near the Agan River, and Irja to Sweden, to meet her husband again. The bakhtinian road chronotope ${ }^{4}$ seems to characterise both journeys, with its potential for encounters. The journey of life, made up of journeys of more symbolic meaning, for example the journey of a little nation, is present as well. There is also the journey of a country that is kept alive only in exile, or in the mind. In Viirlaid's novel, there are two real journeys taking place in parallel: Eigo Arget's voyage to Siberia, and Irja's away from Finland, gradually saying farewell to the country she was born in, while Eigo is under arrest, to the free world. This is the same with Aipin: the Mother of Children is constantly on a border, on her way home, leaving the real world more and more behind. "When will my journey end?" is one of the most often asked questions in both books. According to the beliefs of the Khanty, the World of the Dead is as real for the Mother of Children as is the Middle World she is moving through while travelling across the white snow plains. This is the world fading away in her thoughts: her wellknown, homely world vanishing. The same parallel arises with Estonia in Viirlaid's novel: once one of the Finnish-origin wives asks why her husband has come from that country marked with ill fortune, and the Estonians imprisoned and waiting to be extradited think of their homeland as something already lost and sunk in darkness.

The border of several worlds is here one of the key ideas. The shaman journey of the boreal world-view should be mentioned, as it mixes different religions, different experiences, and the border between the supernatural and the real world is not rigid. In talking about the surrounding world, Tim Ingold has written that "to perceive a landscape is to carry out an act of remembrance, and remembering is not so much a matter of calling up an internal image, stored in the mind, as of engaging perceptually with an environment that is itself pregnant with the past" (Ingold 2007, p. 189). In both novels, although fragmentary as the flight of thought, the completeness of the worldview and its real surrounding environment is evident. The Khanty woman's fate depends on reading the signs in the severe, but beautiful environment she knows so well. The Estonian artist, Irja's husband Eigo Arget, creates his paintings "from the song of the Northern water, forests and air, light breaking through the tragedy of his past and present" - he is trying to find a way of describing his country's fate in art, just as the Khanty woman tries to find, almost up to the end, one peaceful place still existing in the old world. It is remarkable how every detail in Aipin's book forms an irreplaceable part of the picture: the people, the tundra, even a crying wolf. There is actually one more mother to take into consideration: the she-wolf the aeroplane has wounded and whose family is shot by the pilot for fun comes to the Khanty woman desiring to be killed: the wolf hopes, based on her experience, that an encounter with a human defending cattle will lead to this death. So she crawls, mourning for her cubs, to the woman - to receive the coup de grâce.

But Mother of the Children gives her food instead, sharing her last pieces, although the wolf should as well mean danger to her, as a woman with a baby boy with no one to help. Here they are both victims belonging to the old world to be shattered into pieces. ${ }^{5}$ In Viirlaid's novel the name of wolf symbolizes the primeval danger while incorporated into a saying "Hukka on metsässä! (Wolf is in the forest!)" It is the warning for the 
Estonians in Finland about the need of escaping given as a secret parole from one person to another in the middle of conversation.

Both of the novels are deeply religious in a sense with the plurality of religious systems. Actually, the basic values here are not very different, even Eigo Arget of Viirlaid's novel is said to be living in three worlds at the same time, as almost in the Khanty world view:

He tends always to wander in the future not to be expected or turns back into the past, strewing it over with moods born from the present. So he wipes out the reality from his past and changes his future into something thin and unreal. ${ }^{6}$

On both cases, the novels are in a way arguing with God: will it be the Christian one or the Father of the Upper World, with the Orthodox Church and the Khanty tradition strangely interwoven. In Viirlaid's novel a young church clergyman, Harju Kivilo, is doing it openly, accusing his own little faith. And in a more metaphorical sense there are many allusions with the Bible: Eigo Arget's hands have been tied with barbed wire in imprisonment, creating a parallel with bearing a crown of thorns. While arrested, he sees a very vivid dream about Godmother:

Over the slanting crosses and grab stones a black bird came up with slow voiceless flaps of wings, and vanished behind the chapel. On the triangle of the building's gable the face of Virgin Mother, torn by the time, gleamed against the sunset. While staring at her faded glance, Eigo knew, what was coming ${ }^{7}$.

Eigo's and Irja's little son named Agu, with a name meaning daybreak, dies as a redeemer of his father, as Eigo is allowed to take part in his son's funeral. He manages to escape while travelling back to the prison by train and there "begins his journey to the free world."

In the image of the Khanty woman, from the very beginning of the book, there repeatedly emerges the parallel with the Mother of God. The White officer staying with the Khanty sees her sitting above an Orthodox icon, breast-feeding her youngest child and, while wondering what importance this item has in a household of pagans, he notices immediately the striking similarity of the two - the overwhelming beauty and goodness, the glowing tender motherliness radiating from both. In one of the very first scenes of the book, the leader of the Red soldiers suddenly sees two women before him in the chum, unable at first to realize that one is flesh and blood and the other painted: there is a tiny furious Khanty mother with a fur coat surrounding her face, hiding her children behind her back, ready to die, and another one with a baby, gleaming with light, and bearing a halo, on an icon. Later, when the White officer builds a chapel in the Khanty village and paints the faces of the Emperor's family on icons, the Mother of Children looks at them with fear, recognizing the traits of her own family, and asking quietly whether they will have the same gloomy end. She herself addresses Godmother as a friend, a neighbour, a co-sufferer on her journey.

\section{The importance of colors}

The question of colors also arises. Both novels have a few dominant colors: primarily an overwhelming white, as it is winter-time in the books. This color is hostile and is not: the biting frost is said to be the Red prison guard, killing with merciless cruelty. And yet, the white helps and protects as well: the white thick snow enables Eigo Arget to make his jump to freedom from the train, and it lets the arrested Khanty girl escape from the Red Army. White is an ancient Finno-Ugric colour of death: for example, in 
the Komi tradition, it is associated with golden sunlight (Uljashev 1999). White is also the colour of life in the Khanty tradition: the snow is white, the Father from Heaven sends white snow to the Middle World and the sledges go faster then, the soil rests under the thick white snow and the tracks of animals can be seen on it, a snowstorm may hide your trails from the enemy, etc. - so says the Khanty woman, beautiful in her white fur coat.

Irja's color is blue. Blue is one of the important, holy colors of the Finno-Ugrians (Luiga 1995, p. 173). Irja's blue is striped with sunlight, and is the color of the seaside of the Baltic. I would say that the origin of Viirlaid, Estonia, leads us to think as well of the western Estonian coastal waters, first light blue on a summer day, then suddenly breaking into very deep color. Irja's eyes are depicted as deep blue or grey, and when she smiles, it is like the sun shining through the deep waves.

The White officer who visits the Khanty and leaves them, as someone connecting them with the already lost free way of life (this is paradoxical, but still the connection exits) has blue eyes as well. In the Khanty language, they are described as patterned eyes, as the Khanty themselves very rarely have eyes of such color. And there is also a color probably very peculiar to the Khanty world: bog green, the summer color, the color of their own eyes.

Another dominant color in both novels is red, the contrast color of life..$^{8}$ In both books, we perceive the importance of the last association: life pouring out of bodies, leaving red stains on the snow. It is interesting that the very first colors in a language are light and dark, or black and white (also marking the contrast of warm and cold), and then the third to arise is red. This goes as far back as the Finno-Ugric original language (Sutrop 1996, p. 664). In Estonian, there is the old word verev *wire 'veri' (blood), in Khanty wərtə 'red' < wər, and in Hungarian it is vörös, vërës.

The light white, almost golden, with stripes of sun, is like a halo around the heads of both of the women. A "golden, sun-like woman" was a phrase that crossed my mind while finding the words to describe Aipin's and Viirlaid's female characters. This is mainly because "Golden Woman" is one of the oldest Estonian lyrical-epic runo songs in the Finno-Baltic region, 2000-3000 years old. As it has been sung by women, it reflects their hopes and secrets, explaining feminine self-cognitive values (Ehin 2002).

The topic of the song is a cultural myth to be found all over the world, particularly in Eastern nations. In the song, a young man makes himself a golden or wooden wife, a perfect one. For example, in the Finnish-Karelian folk song, the blacksmith Ilmarine forges a woman made of gold from Heaven. But he is disappointed, finding out that a mortal woman is better, having five things a most beautiful metal lady will never possess (Jaago 1993, p. 18-19). A mortal woman has the ability to speak with the world, with other people and with God; she has the mind (or memory) to remember things; she has a warm heart; she has a soul; and she has a warm body, the home of the soul (Sarv 1990). So the real golden woman is not a forged one. The writers discussed in this article are both men, creating their female protagonists as an ideal, but one thing is sure from the beginning: their ideals, their "golden women", have those five qualities. Viirlaid's character Armin, in a Siberian labour camp, describes his ideal woman: she must be a companion through life, someone who can always be trusted. ${ }^{9}$ Both women in the novels are the centers of their surrounding worlds, the warm heart of their home Irja in the home of an artist, full of the blue morning light from the bays and straits, with the freedom to come and go that the restless spirit of an artist may need. Irja does 
not know much about Eigo's past, but she wants to make him forget the pain he has suffered, while Eigo's attitude towards the future is complicated: he imagines his present idyllic life as a sand castle on a beach to be broken in the next moment by a giant. Irja would run straight into the fire for each member of her family; this is the way the Khanty mother thinks, word-for-word, about her own family. She is good, tender and strong as well, and she is the most important person in the household, after the master of the house. Estonian historians have stated that the ancient position of a woman in society was probably quite high; the pre-Christian family model was quite well balanced, more so than in the Indo-European cultures (Mägi 2003, p. 34).

What should the happy life of a Khanty woman look like? The Mother of the Children says this to her dying daughter (this is in the form of a lamentation):

You will have many sunny days ahead! You will have many moonlit days ahead! [...]

You will have much needlework ahead, you will have many patterns-ornaments...

And then comes a clear cloudless day when a man with three white reindeer comes

after you and you will become the housewife of your own home and the keeper of

your hearth and home and a beloved wife and a caring mother and a good

grandmother..." ${ }^{10}$

Secondly, the image of the Golden Woman is also connected with the original FinnoUgric mother of the sun, the wife of the God of Heaven. Anna-Leena Siikala has written about the possible connection of the southern abode and the sun as a Great Mother in the Uralic nations' mythology in the Finnish folk song - the Goddess of the Sun and day and light - and has also said that, during the Middle Ages, the Goddess was replaced by the Virgin Mary (Siikala 2000, p. 133-134). Estonia has long been called the Land of Mary, since the $13^{\text {th }}$ century. Besides the Catholic tradition, the process of giving this name was connected with honoring the Golden Woman. The Virgin Mary and the mythical golden woman had much in common before the Reformation - they probably formed one figure, blended into each other, and in Estonia the Mary cult is still preserved, for example, in the names of plants (maarjalepp, maarjalil, maarjamaltsl, etc.) (Sivers 1988, p. 30).

\section{The ones to carry the world}

31 A mother must be good and tender, but also strong (Aipin 2008, p. 154), as is the Earth itself. In Aipin's novel, the Mother of Children turns repeatedly to Mother Sun and Mother Earth (ibid p. 228-229, p. 250), like their younger sister or daughter.

Women are supposed to know "traditional" knowledge. Irja holds the fragile world together for Eigo. The Khanty Mother constantly remembers, explains and consoles. How to remember is a question that often arises. For example, the traditional embroidery and handicrafts of the Khantys is described through the Mother of Children interpreting the imagined fur coats of the Emperor's family so that every part of the needlework has a certain meaning as a piece telling about their life journey. Often it is the women who have to carry on the traditions - obviously also a way of telling about the past - because they are the only survivors when men go to war.

And a Golden Woman cannot lack pride. Pride characterizes both women. Eigo Arget concludes: "Had it not been so with all the Finno-Ugric nations: their pride and pain go hand in hand as twin brothers." Irja stays with her husband, sharing with him homelessness. The Mother of Children dreams of becoming a sniper to fight till death, 
to get revenge. She has already become one of the mythical heroines while shooting down the aeroplane. Art Leete has described the parallels with a fairy-tale: she has visions of the mythical bird Kars eating her flesh (Leete 2009, p. 223; see also Leete 2009, p. 228).

\section{Conclusion: the experience of little border nationsand universal parallels}

At the end of Aipin's novel, a Khanty girl manages to escape from soldiers (she is probably the oldest daughter of the Mother of Children, coming to meet them with her young husband when she was captured). Irja Arget gives birth to a little girl before leaving her homeland.

Both of the novels show different worlds or world systems clashing with almost unimaginable cruelty: the pilot shooting little Khanty girls on the snow, and the prison guards tearing Eigo Arget away from his ill, dying son.

This represents the experience of a little nation in a borderland. The novels are both written by fighters, with the world not black-and-white here, not fighting against something, but fighting for something, for the opportunity to create and live in one's own nation, on a piece of land remembered and interpreted, with a given meaning often reflected in language.

Viirlaid writes:

So their life was cut into two. Air and light, day and night were left to them, but further on it was all different. The same feelings and yearnings were left to them, but no one any longer considered them to be men, as it had been yesterday. ${ }^{11}$

This is about the right to be a man with a world, with his own belief. Those words may as well have been written in Boris Pasternak's Doctor Zhivago (1957), or in Anatoli Rybakov's The Children of the Arbat.

Although the events of the past do not show mercy, there is still a tiny piece of future at the end of both novels: the Khanty boy is taken to a Khanty village by the white sledge dog Poitek, the Khanty girl escapes over the snow fields, and Eigo's younger children leave with their mother for Sweden on board a ship. They won't have the country in which they were born, but they will have it with them - to remember and, as a conclusion of both of the novels, to tell as a post-memorial story "etched into memory space" - very closely connected to the question of creating and preserving identity, ${ }^{12}$ here through literature. An act of remembrance is in both novels supported by the landscape - the visible and perceivable natural environment, and the spiritual world of memory inseparable from it - "pregnant with the past". And there is the mutual belief in a Golden Woman who is able to carry the world.

The historical circumstances of little nations probably make it easier for them to understand each other, but the numerous parallels point to age-old resemblances of telling, remembering and perceiving the world. 


\section{BIBLIOGRAPHY}

AIPIN 2002 = АЙПИН ЕРЕМЕЙ ДАНИЛОВИЧ, БОЖЬЯ МАТЕРЬ В КРОВАВЫХ СНЕГАХ, ЕКАТЕРИНБУРГ:

ПАКРУС.

ASSMANN Jan, 2008, “Communicative and Cultural Memory”, Cultural Memory Studies. An

International and Interdisciplinary Handbook, Eds: Astrid Erll; Ansgar Nünning, p. 109-118.

BAKHTIN Mihhail, 1987, „Aja ning kronotoobi vormid romaanis“, Valitud töid, Tallinn: Eesti Raamat.

EHIN Kristiina, 2002, „Mehed teevad naist: regilaulu „Kuldnaine“ tähenduskontuure“, Ariadne lõng,

$1 / 2$, p. $62-72$.

HIIEMÄE Mall, 2007, 2008, „Lepp - lepakarva puu“, Sõnajalg jaaniööl, Tartu: Ilmamaa, p. 264-269.

INGOLD Tim, 2007, The Perception of the Environment: Essays on Livelihood, Dwelling and Skill, London: Routledge.

JAAGO Tiiu, 1993, Kuldnaine [rahvalaulutüübist], Tartu: Tartu Ülikooli Kirjastus.

LEETE Art, 2002, Kazõmi sõda. Šamanistliku kultuuri allakäik Lääne-Siberis, Tartu Ülikooli etnoloogia

õppetool, Tartu: Tartu Ülikooli kirjastus.

LEETE Art, 2009, "The role of young people in resistance against the soviet rule among the

Northern peoples in the 1930s-1940s", Electronic Journal of Folklore, Vol 41

http://www.folklore.ee/folklore/vol41/leete.pdf

LACHMANN Renate, 2008, "Mnemonic and Intertextual Aspects of Literature", Cultural memory studies. An international and interdisciplinary handbook. Astrid Erll, Ansgar Nünning in collaboration with Sara B. Young (Eds.), Berlin; New York: Walter de Gruyter, p. 301-310.

LUIGA Juhan, 1995, „Eesti lipu värvid“ in Luiga, Juhan. Hingejõu ilmed, Hando Runnel (Ed.), Tartu: Ilmamaa, p. 173-175.

MÄGI Marika, 2003, Eesti aastal 1200, M. Mägi (Ed.), Tallinn: Argo.

SARV Mikk, 1990, „Laul Kuldnaisest“, Kultuur ja Elu, 8, p. 12-13.

SIVERS Fanny de, 1988, „Maarjamaa ja Maarja“, Tulimuld, 1, p. 29-34.

SIIKALA Anna-Leena, 2000, "What Myths Tell about Past Finno-Ugric Models of Thinking", Congressus Nonus Internationalis Fenno-Ugristarum 7, 13.8.2000 Tartu. Pars I. Orationes plenariae \& Orationes publicae. Tartu, p. 127-140.

SUTROP Urmas, 1996, „Eesti keele värvussõnavara arengu põhijooni“, Keel ja Kirjandus 10, p. 661674.

TOULOUZE Eva, 1999, „Traagiline jõud ja rahulik jõud“, Looming, 11, p. 1698-1705.

TOULOUZE Eva, 2004, „Venemaa põhjarahvaste eliit: kuulekusest vastupanuni (Euroopa ja Lääne-

Siberi arktiliste alade näitel)“, Estonian Social Science Online, Eesti sotsiaalteaduste V

aastakonverentsi erinumber

http://www.sotsioloogia.ee/vana/esso3/15/eva_toulouze.htm

ULJASHEV Oleg, 1999, „Värv komide ettekujutustes ja rahvaluules“, by Nikolai Kuznetsov

http://www.folklore.ee/seminar/uljashev.html

VIIRLAID Arved, 1990, Märgitud, Tallinn: Perioodika. 


\section{NOTES}

1. "Eremei Aipin fights with words" (Toulouze 2004).

2. Viirlaid is the most translated exile writer of Estonia; his novel Graves Without Crosses (Ristideta hauad, 1952) has appeared in nine languages.

3. In the 1990ies it was at last possible to talk about the resistance in the early Soviet period (Leete 2009, p. 227).

4. In a chronotope, time thickens and becomes artistically visible; likewise, space becomes charged and responsive to the movements of time, plot and history. On the road - inside the road chronotope - the most different fates may meet, collide or interweave with one another (Bakhtin 1987, p. 55).

5. The crying reindeer is a motif I have found previously in the literature of the Nordic nations.

6. "Aina tikub ta uitlema tuleviku olematuses või pöördub minevikku, mille puistab üle oleviku meeleoludega. Nii kustutab ta oma minevikust tõelisuse ja muudab oleviku õhukeseks ja ebatõeliseks" (Viirlaid 1990, p. 7).

7. "Vildakuti vajunud ristide ja hauakivide kohalt tõusis aeglaste hääletute tiivalöökidega must lind ja kadus kabeli taha. Hoone viilualuse kolmnurgal helkis vastu päikeseloojangut ajahambast puretud Neitsi Maarja nägu. Vahtides üksisilmi selle kustunud pilku, teadis Eigo, mis tulemas" (Viirlaid 1990, p. 96).

8. Mall Hiiemäe has written that, in the Finno-Ugric tradition, the alder, a tree that produces red timber, is the tree of the soul, and in the Khanty folklore only alder trees grow in the highest World of the Dead (Hiiemäe 2007, 2008, p. 266).

9. He actually knows such a girl: given a boy's nickname, Peeter, with a snub nose and shingled hair; a brave girl from Tallinn has come with these men to Siberia. Later she is killed by soldiers.

10. У ТЕБЯ ВПЕРЕДИ ЕЩЕ МНОГО СОЛНЕЧНЫХ ДНЕЙ! У ТЕБЯ ВПЕРЕДИ ЕЩЕ МНОГО ЛУННЫХ ДНЕЙ! [...] У ТЕБЯ ВПЕРЕДИ ЕЩЕ МНОГО СТЕЖЕК-ДОРОЖЕК, У ТЕБЯ ВПЕРЕДИ ЕЩЕ МНОГО УЗОРОВ-ОРНАМЕНТОВ... И НАСТУПИТ КОГДА-НИБУДЬ ЯРКИЙ БЕЗОБЛАЧНЫЙ ДЕНЬ: НА ТРЕХ БЕЛЫХ ОЛЕНЯХ ПРИМЧИТСЯ ЗА ТОБОЙ ЧЕЛОВЕК, И СВОЕГО ДОМА ТЫ СТАНЕШЬ ХОЗЯЙКОЙ, И СВОЕГО ОЧАГА ТЫ СТАНЕШЬ ХРАНИТЕЛЬНИЦЕЙ, И СТАНЕШЬ ЛЮБИМОЙ ЖЕНЩИНОЙ, И СТАНЕШЬ ЛАСКОВОЮ МАТЕРЬЮ, И СТАНЕШЬ ДОБРОЮ БАБУшкой

(version en ligne http://loveread.ws/read_book.php?id=35229\&p=12)

11. "Niiviisi lõigati nende elu pooleks. Neile jäi õhk ja valgus, päev ja öö, kuid edaspidi oli see kõik erinev. Neile jäid samad tunded ja igatsused, kuid keegi ei pidanud neid enam inimesteks, nagu nad olid olnud eile" (Viirlaid 1990, p. 160).

12. Art Leete has shown how resistance still plays an important role in the identity of the northern peoples (2009, p. 227). 


\section{ABSTRACTS}

This paper will analyse the similarities between two novels, the Estonian Arved Viirlaid's Marked, (Märgitud, 1980) and Yeremei Aipin's The Mother of God in Bloody Snow (2002), both of which reflect deeply painful experiences of small nations. The special interrelationship proceeds from different dimensions: in the first place, from similar periods of the past, involving events that can be compared. Aipin's novel deals with the armed uprising of the Khanty and Nenets people, known as the Kazym War (1933-1934). This pain is also what is common and familiar in both novels. Both books are largely narrated from the viewpoint of women, a Khanty wife and the Finnish wife Irja. Although the events of the past do not offer mercy, there is a tiny piece of bright future at the end of both novels: the Khanty boy is taken to the Khanty village by the sledge dog Poitek, and the half-Estonian, half-Finnish boy and girl leave with their mother for Sweden on board a ship. Two very important and very complicated parallels between these two novels are the cognition of nature and the characters' perception of the world. This paper tries to answer the question of how common experiences are reflected in these two novels, and how this creates a common sphere of understanding.

Les romans Marqué (1980) d'Arved Viirlaid, un écrivain estonien de l'émigration, et La mère de Dieu dans les neiges de sang (2002) uisent leur inspiration l'un comme l'autre dans l'histoire. Ils racontent deux itinéraires : celui de l'artiste estonien Eigo Arget, qui a combattu dans la guerre de continuation, et de son épouse finnoise Irja, qui ont pu passer dans le monde libre d'une part, et celui de la Mère des Enfants, une femme khantye, allant jusqu'à un village khanty pendant la guerre du Kazym. En chemin, l'un comme l'autre perdent tout ce qu'ils ont, tout ce en quoi ils croyaient. Pourtant, un rayon de soleil apparaît à la fin des romans : même pour les petits peuples pris en tenaille dans les rouages de l'histoire, l'espoir est permis. Cet article compare les univers de ces deux romans, les systèmes de croyances, leur description et leur évocation, la spécificité du rôle des femmes, et s'interroge sur les traits communs éventuels entre littératures finno-ougriennes.

Välis-Eesti autori Arved Viirlaiu romaan „Märgitud“ (1980) ja handi kirjaniku Jeremei Aipini romaan „Jumalaema verisel lumel“ (2002) tõukuvad mõlemad ajaloost ja kõnelevad teekonnast: Jätkusõjas võidelnud eesti kunstnik Eigo Argeti ja tema soomlannast abikaasa Irja pääsemisest vabasse maailma ning handi naise, Laste Ema teest koju handi asulasse Kazõmi sõja päevil. Mõlemad kaotavad sel teekonnal peaaegu kõik, millesse uskusid, ometi on raamatute lõpul lootuskiir, et ka ajaloo rataste vahele jäävad väikerahvad ei jäta lootust. Artiklis on võrreldud romaanides loodud omailmu, uskumussüsteeme, nende kirjeldamise ja mäletamise viise, naise rolli erilisust ning võimalikke ühisjooni soome-ugri kirjanduste vahel. 
INDEX

nomsmotscles Estoniens, Khantys, Nénetses

Mots-clés: émigration, Armée blanche, guerre du Kazym, Frère de la forêt, nature, Guerre de continuation, Guerre du Kazym, vision du monde, Guerre d'indépendance, Ostiak, Tchoum

Geographical index: Agan (rivière), Angleterre, Canada, Finlande, Sibérie, Suède

disciplines finnois, estonien, hongrois, khanty, russe

Subjects: littérature comparée

Chronological index: XXe siècle (fin), XXIe siècle (début), XXe siècle, XXIe siècle

Keywords: Kazym war, Comparative Literature, Emigration, end of the 20th century, beginning of the 21st century, Estonian, Finnish, Hungarian, Khanty, Russian, Estonians, Agan, Canada, England, Finland, Siberia, Sweden, Varyogan 